\title{
イメージグリッド法を用いた健康形成要因構造に関する研究 STUDY ON THE HEALTH RELATED FACTOR MODEL BY THE IMAGE GRID METHOD
}

高 橋浩伸*, 大井尚行**

Hironobu TAKAHASHI and Naoyuki OI

\begin{abstract}
The concept of "health" is thought to be important to today's housing. In order to overcome the difficulty in investigating the concept of "health", the Image Grid Method was developed from Evaluation Grid Method and the concept of Behavior settings in our previous study.

A questionnaire survey on "health" was conducted using the Image Grid Method in 2009 on 75 people of various attributes: living area, gender, age, housing type, health condition etc.

Resulation from this study are found to be the complementary knowledge with the previous studies on the health related factors using other approaches.
\end{abstract}

Keywords : Health related factor model, Image Grid Method, Health, House environment, Evaluation construct 健康形成要因構造，イメージグリッド法，健康，住環境，評価構造

\section{1. 研究の背景と目的}

今日の住宅は、『賢くなる家』や『癒される家』等に代表されるよ うに、単に光環境や温熱環境等の環境要因による快適性だけではな く、心理・生理的付加価値を謳い文句にした提案が多く目につくよ うになっている。中でも「健康」をキーワードとした住宅の重要性 が増したのを受けて、国土交通省は、国民の居住ニーズの多様化・ 高度化等の課題に対して、住宅や地域の健康環境品質を向上し、生 涯健康・生涯現役を実現するための新たな住宅環境やコミュニティ のあり方を検討する必要性から、平成 19 年に健康維持増進住宅研究 委員会を設立した。

このように健康という概念は、今や住宅にとって重要な概念と言 えるが、“健康である”“健康でない”という評価には個人差や時間 的流動性、天候や気分等による影響などあいまいな部分が多い。 そこで筆者らは既往の研究 ${ }^{1)}$ において、“健康”という概念自体 に着目し、その概念構造を把握するためにイメージグリッド法 ${ }^{1)}$ 開発し、“健康”の概念がどのような要因によって形成されているか といった健康の概念の構造モデルを示してきた。

これまで健康に関しては、住環境との関係性において建築や医学 の分野で多くの研究がなされている。特に建築の分野だけを見ても、 室内污染物質による健康被害に関する研究 ${ }^{2)}$ や住宅の温熱環境が居 住者の健康に与える影響に関寸る研究 ${ }^{3}$.4)、また居住者の生活様式
と健康障害に関寸る研究 ${ }^{5 、 6)}$ や戸建て住宅の環境性能と居住者の健 康状態に関する調査研究 ${ }^{7)}$ があり、更に、安藤らによる住宅とその 周辺環境が住民の健康維持増進に及ぼす影響に関する研究等 8 10) が見られる。これらの既往の研究 ${ }^{2 \sim 10)}$ における健康状態を知るた めの調査手法は、問診票や選択回答式アンケート調査等が用いられ ているが、これらはいわゆる健康に関する演繹的推論によって作成 されたものと言える。また、安藤らの研究 ${ }^{8)}$ では、これらのアンケー 卜調査により、健康の概念の形成要因の構造モデルを示したものも 見出せる。一方、筆者らが行った既往の研究 ${ }^{1)}$ のような自由記述式 アンケート調查による健康に関する帰納的アプローチを用いた研究 は見い出すことができない。

そこで本研究は筆者らの既往の研究 $\left.{ }^{1}\right)$ を更に分析を進め、より詳 細な健康の形成要因の構造モデルを示し、既往の演繹的アプローチ による健康形成要因構造モデル ${ }^{8)}$ との違いがあるかを見極め、演繹 的アプローチでは見いだせなかった健康という概念の新たな知見を 示すことを本研究の目的とする。このようなことを行うことで、健 康に関する理解をより深め、今後の健康と住環境との関係性の研究 に貢献したい。

\section{2. 調査手法}

筆者らは既往の研究 ${ }^{1)}$ において、イメージグリッド法を開発した。
* 熊本県立大学 環境共生学部 准教授 $\cdot$ 博士 (工学)

** 九州大学 大学院芸術工学研究院 准教授. 工博
Assoc. Prof., Faculty of Environmental \& Symbiotic Sciences,

Prefectural University of Kumamoto, Dr.Eng.

Assoc. Prof., Faculty of Design, Kyushu University, Dr.Eng. 
個人の環境評価構造を抽出する手法としては評価グリッド法がある が、“健康”という概念は、評価グリッド法で扱う概念としての “住宅” や “オフィス” 等の場所に限定されたものではなく「人間・環境系」 で考えた場合の人間側、環境側の双方にまたがる概念であるため、 評価グリッド法を用いようとする場合、比較判断を行うための比較 対象（エレメント）を環境側に限定して用意することが難しかった。 そのため新たに開発したイメージグリッド法では、人間・環境系の 研究における「行動場面」(Behavior setting) の概念を導入し、評 価グリッド法でいうオリジナル評価項目の抽出を行う等の変更がな されている11)

\section{3. 調査の概要}

本調査では図 1 に示したアンケート用紙を配布・回収することで データを得た。“健康”という概念が個人的・流動的な概念であるた め、様々な属性の回答者のデータが必要と考え、配布対象地域を複 数選定し、性別、年齢、現在の住まい、健康状態といった項目につ いても回答してもらうことにした。配布・回収は健康維持増進住宅 研究コンソーシアム参加各社および委員を通して行った。2009 年 4 〜 5 月にかけて 70 名分のデータが回収され、その後郊外 3 名、農 山村 2 名の追加があり、計 75 名となった。被験者の属性等を表 1 に示す。

\section{4. 行動場面のカテゴライズと回答率}

本研究は、個人の評価構造を抽出することが目的ではなく、個人 のデータを組み合わせることで多数の人に共通寸る “健康”に関寸 るイメージ構造の概要を把握することが目的であるが、従来の評価 グリッド法のように全ての被験者の評価構造をひとつの図にまとめ ようとすると、評価構造図があまりに巨大化してしまい、図として 機能しにくいと考えられた。また、“健康”という概念が特定の場に 限定されず、環境概念のまとまりがつけにくいために被験者へのア ンケートでは、「健康と感じる時」という“行動場面”を記述しても らうこととした ${ }^{1)}$ 。

\section{調 査 票}

この調查は、全てあなた自身について1人でお答えください。

のあなたが生活している中で、「健康的だと感じるとき」を思いつくままに5つ教えてください。 健康には「身体的な健康」とリラックスできるといった「心理的な健康」の両方を含みます。 大げさに考えず気軽に5つ挙げていただければと思いますが、どうしても思い浮かばない場合は らつにならなくてもかまいません。

健康的だと感じる時 $(1)$

健康的だと感じる時 $(2)$

健康的だと感じる時 (3)

健康的だと感じる時 $(4)$

健康的だと感じる時 (5)

ここでは、自身で行動場面を挙げて もらいます

・健康的だと感じるとき（1）についてうかがいます。

ロそのようなときとして思い浮かんだ場面を詳しく書いてください。

(いつどこで誰と何をしているか等）複数の場面が思い浮かぶ場合は。それぞれお書きください ここには、自身で挙げてもらった行動場面を具体的に書いてもらいます

口「健康的だと感じるとき（1)」で健康的だと感じるのはなぜでしょうか。具体的な理由や、 どの上うに健康に良いイメージにつながっているのか、をくわしく説明してください。 ここでは、ラダーアップを誘導します

口「健康的だと感じるとき（1)」のように感じるために適した場所や周囲の条件について、 どんなことでもかまいませんのでいくつでも挙げて、それぞれ詳しく説明してください。

ここでは、ラダーダウンを誘導します

図 1 本調査におけるアンケート用紙 ${ }^{1}$
アンケート結果より行動場面のカテゴライズを行った。行動場面 は「運動」「食事」「睡眠」「入浴」「家族」「自然」「思考」「趣味」仕事」「そ の他」の 10 のカテゴリーに分類でき、更に 10 に分けたカテゴリー の中でもいくつかのユニットに細分化を行った。その詳細を図 2 に 示す。

$$
\text { [カテゴリー］【【ユニット】 }
$$

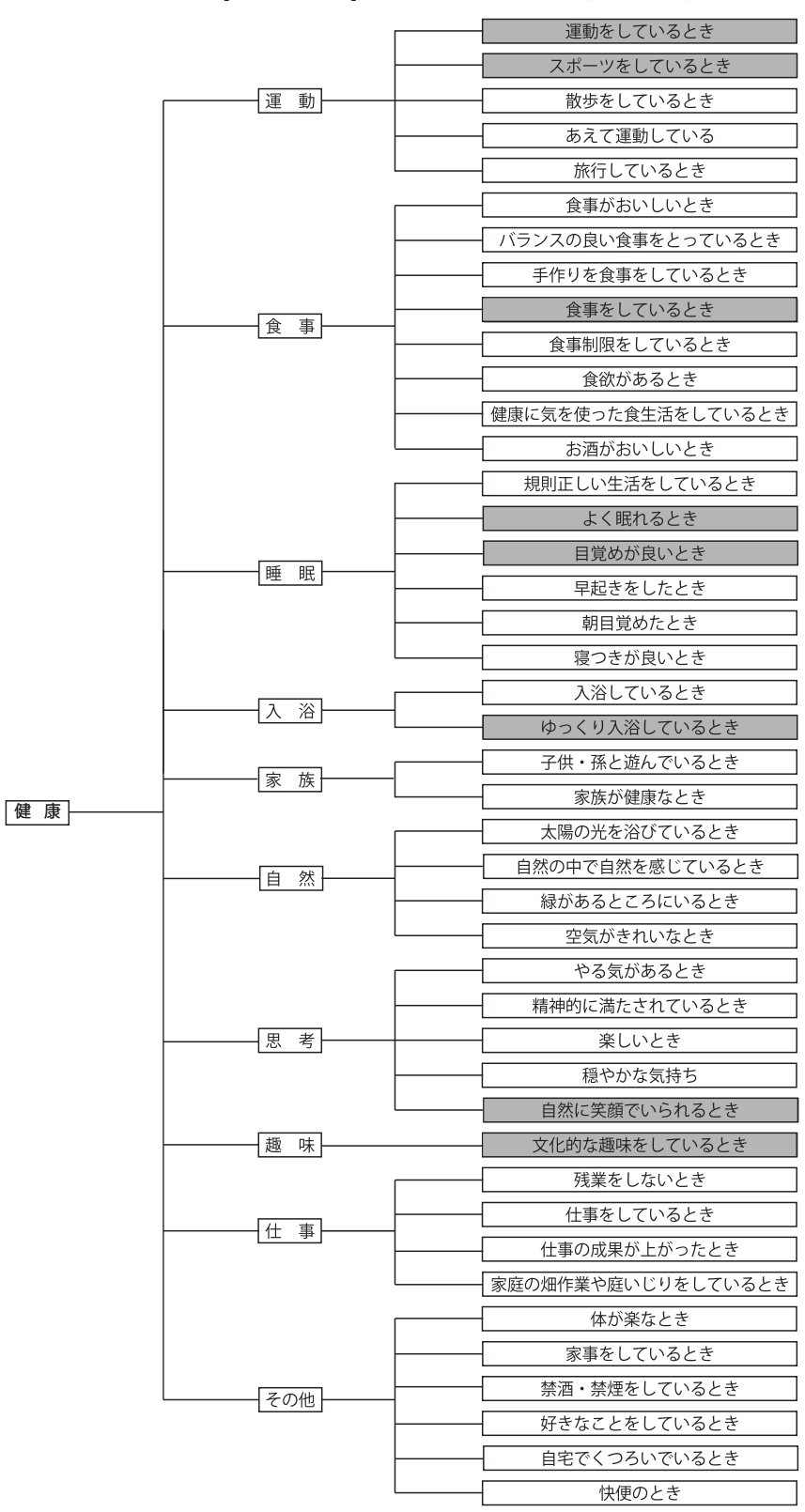

※ 図 2 は既往研究 1 ) を基に作成

※ 口 は本調査結果において複数の人が挙げた要因を多く含むものを示す。 図 2 健康のカテゴリーとユニット

\section{表 1 被験者の属性 ${ }^{1}$}

\begin{tabular}{|c|c|c|c|c|c|}
\hline 計 & \multicolumn{2}{|c|}{ 男性 } & \multicolumn{2}{|c|}{ 女性 } & 未回答 \\
\hline 75 & \multicolumn{2}{|c|}{44} & \multicolumn{2}{|c|}{30} & 1 \\
\hline \hline 20 歳代 & 30 歳代 & 40 歳代 & 50 歳代 & 60 歳代 & 70 歳代 \\
\hline 10 & 36 & 17 & 5 & 5 & 1 \\
\hline \multirow{2}{*}{ 現在の住まい } & \multicolumn{2}{|c|}{ 戸建住宅 } & \multicolumn{2}{|c|}{ 集合住宅 } & 未回答 \\
\cline { 2 - 6 } & \multicolumn{2}{|c|}{27} & \multicolumn{2}{|c|}{40} & 8 \\
\hline \multirow{2}{*}{ 現在の住まい } & \multicolumn{2}{|c|}{ 持家 } & \multicolumn{2}{|c|}{ 賃貸 } & 未回答 \\
\cline { 2 - 6 } & \multicolumn{2}{|c|}{42} & \multicolumn{2}{|c|}{30} & 3 \\
\hline \multirow{2}{*}{ 現在の住まい } & 都心部 & 都市郊外 & 農山村等 & 未回答 \\
\cline { 2 - 6 } & 32 & 31 & 9 & & 1 \\
\hline
\end{tabular}


表 2 行動場面ごとの回答率

\begin{tabular}{|c|c|c|c|c|c|c|c|c|c|c|c|}
\hline & 運動 & \begin{tabular}{|l|} 
食事 \\
\end{tabular} & \begin{tabular}{|l|} 
睡眠 \\
\end{tabular} & 入浴 & 家族 & 自然 & 思考 & 趣味 & 仕事 & その他 & 計 \\
\hline 全体 & 68 & 66 & 65 & 16 & 10 & 25 & 31 & 17 & 13 & 31 & 342 \\
\hline (\%) & 19.9 & 19.3 & \begin{tabular}{|l|l}
19.0 \\
\end{tabular} & 4.7 & 2.9 & 7.3 & 9.1 & 5.0 & 3.8 & 9.1 & 100 \\
\hline 男 & 43 & 44 & 37 & 11 & 5 & 11 & 10 & 14 & 13 & 11 & 199 \\
\hline (\%) & 21.6 & 22.1 & \begin{tabular}{|l|}
18.6 \\
\end{tabular} & 5.5 & 2.5 & 5.5 & 5.0 & 7.0 & 6.5 & 5.5 & 100 \\
\hline 女 & 23 & 26 & 28 & 5 & 5 & 14 & 21 & 3 & 2 & 20 & 147 \\
\hline (\%) & 15.6 & 17.7 & 19.0 & 3.4 & 3.4 & 9.5 & 14.3 & 2.0 & 1.4 & 13.6 & 100 \\
\hline 20 歳代 & 10 & 9 & 14 & 1 & 1 & 4 & 8 & 2 & 1 & 2 & 52 \\
\hline (\%) & 19.2 & 17.3 & 26.9 & 1.9 & 1.9 & 7.7 & 15.4 & 3.8 & 1.9 & 3.8 & 100 \\
\hline 30 歳代 & 35 & 35 & 27 & 8 & 4 & 17 & 16 & 10 & 3 & 15 & 170 \\
\hline (\%) & 20.6 & 20.6 & 15.9 & 4.7 & 2.4 & 10.0 & 9.4 & 5.9 & 1.8 & 8.8 & 100 \\
\hline 40 歳代 & 14 & 15 & 14 & 5 & 3 & 2 & 7 & 4 & 2 & 9 & 75 \\
\hline (\%) & \begin{tabular}{|l|}
18.7 \\
\end{tabular} & 20.0 & \begin{tabular}{|l|}
18.7 \\
\end{tabular} & 6.7 & \begin{tabular}{|l|}
4.0 \\
\end{tabular} & 2.7 & \begin{tabular}{|l|}
9.3 \\
\end{tabular} & 5.3 & \begin{tabular}{|l|}
2.7 \\
\end{tabular} & 12.0 & 100 \\
\hline 50 歳代 & 5 & 5 & 3 & 2 & 0 & 2 & 0 & 2 & 1 & 3 & 23 \\
\hline (\%) & 21.7 & 21.7 & 13.0 & 8.7 & 0.0 & 8.7 & 0.0 & 8.7 & 4.3 & 13.0 & 100 \\
\hline 60 歳代 & 4 & 7 & 3 & 0 & 2 & 0 & 1 & 0 & 4 & 5 & 26 \\
\hline (\%) & 15.4 & 26.9 & 11.5 & 0.0 & \begin{tabular}{|l|}
7.7 \\
\end{tabular} & 0.0 & 3.8 & 0.0 & 15.4 & 19.2 & 100 \\
\hline
\end{tabular}

表 2 には、各行動場面のカテゴリーごとの回答者数と、各属性（性 別、年齢) における回答者数の割合を示寸。またこの表 2 から行動 場面ごとの回答率（性別および年代別）をグラフにしたものを図 3、 図 4 に示す。表 2 より、「運動」「食事」「睡眠」の 3 つのカテゴリー に関する回答数が全体の約 6 割を占めることがわかる。この傾向は、 性別や年代別にも見られる。すなわち「健康」という概念にとって 「運動」、「食事」、「睡眠」という行動場面との関係性が高いことが見 て取れる。

行動場面ごとの違いを見ていくと、図 3 より性別で違い見られる のは「思考」であり、女性が男性よりも回答率が高い。このことか ら女性の方が精神的な状況と健康との関係性が高いこと見て取れる。 また、それとは逆に「趣味」や「仕事」は、男性が女性よりも回答 率が高い。これは男性にとって仕事や趣味が健康に結び付きやすい ということが見て取れる。更に図 4 より年代別で見てみると、食事」 に関しては、年齢が高くなるにつれて、回答率が高くなる傾向が見 られる。これは中高年になり、健康に不安を感じる年代になると、 食事の重要性を認識するようになるからであろう。「睡眠」に関して は、20 歳代の回答率が最も高く、20 歳代にとって「睡眠」は健康と の関係性が他の年代より高く、眠ることで健康へとつながると考え ているようである。全体としては「食事」とは逆に年代が高くなる につれて回答率は低くなるようだが、40 歳代は回答率が高くなって いる。総務省が毎年行っている「平成 23 年社会生活基本調查生活 時間に関する結果 $\left.{ }^{11}\right)$ を見てみると、45 歳前後の睡眠時間が最も少 ないというデータが出ており、働き盛りの時間的余裕の無さや体調 の変化の時期による、睡眠と健康との関係性が強く示された結果で はないかと考えられる。「思考」に関しては、年代が低い方が回答率 の割合が高くなる傾向が見られる。これは若い世代は精神的状況が 健康に影響を及ぼしや寸い傾向が見て取れる。

\section{5. 構造モデルの分析及び考察}

イメージグリッド法においては、調査時にラダーアップ、ラダー ダウンを行っているため、回答は単なる項目の指摘ではなく、項目 間のつながりがデータとして得られている。このことを利用して、 評価構造モデルを作成し、これらの構造モデルから健康形成要因を 見出していく。

本研究においては、まず図 5 の作成手順に従い個人の評価構造モ デルを作成した。これら個人のデータをすべて組み合わせ、全体の
評価構造モデルを作成するには、被験者数が多く巨大化が予想され たため、全体の評価構造モデルを作成せず、図 2 のカテゴリーごと の評価構造モデルを図 6 の手順で作成した。

イメージグリッド法では、評価グリッド法同様、ラダーリングを 行うが、図 1 にあるようにひとつの回答欄にイメージされる項目や 内容を詳しく記述するよう求めているため、ひとつの回答欄には複 数の内容が含まれているケースが多い。そこでラダーアップにおい て、「○○だから××」と回答されれば、図 5 に示すようにこれら を 2 つに分け、「メ×」をより上位に「○○」をより下位の評価項 目とした。

複数人の個人データを組み合わせる場合、被験者の回答した複数 の言葉の内容が同じであると見なし得る場合は、それらを一つに言 葉としてまとめている。例えば、行動場面として被験者 A が「ゴル フをしているとき」、被験者 B が「テニスをしているとき」と回答し、 ラダーアップでは A が「汗をかく」、体を動かす」、 B が「体を動か寸」、 「リフレッシュできる」、ラダーダウンでは A が「ゴルフ場」、「天気 が良い」B が「天気が良い」「「テスコート」と回答したものをま とめる場合、行動場面の「ゴルフをしているとき」と「テニスをし ているとき」は「スポーツをしているとき（2)」（カッコ内の数字は、 その言葉が使用された数を示寸) とし、ラダーダウンでの「ゴルフ場」 「テニスコート」を「運動施設 (2)」というようにまとめることとし た（図 6 参照)。

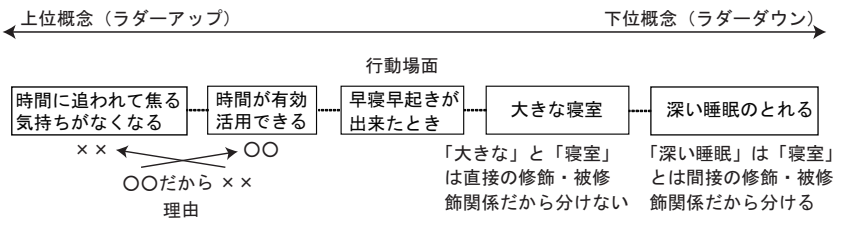

図 5 個人の評価構造モデルの作成手順の例 ${ }^{11}$

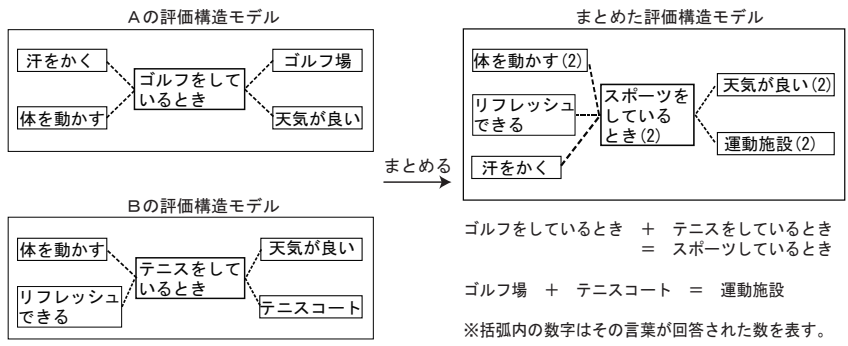

図 6 複数人の評価構造モデルの作成手順の例 ${ }^{11}$ 


\section{1. カテゴリー「運動」}

図 2 に示すように、カテゴリー「運動」において特徵的な構造モ デルは、【運動しているとき】【スポーツしているとき】である。こ れらの構造モデルを図 7-1、7-2 に示す。

図 7-1 より、【運動しているとき】に関しては、運動していると きに健康だと感じる要因を示寸構造図右側の下位概念として、［空 気が良い][陽射し ] [ 自然の中 ] [ 快適な温湿度 ］などの環境条件 が必要であることがわかる。また今日、日常生活では感じることの 少なくなった [ 風 ] や [ 空気のにおい ] 等 [ 日ごろ感じることの ない］環境条件も健康との関係性がうかがえる。次に構造図左側の 健康だと感じる場合のベネフィットとしての上位概念を見てみると、 [体を動か寸] [ 運動不足の解消］[メタボ等の解消］といった、体 を動かし汗をかくことが健康へとつながると考えているようである。

次に図 7-2 より、【スポーツしているとき】に関しては、まず右 側の下位概念をみると、【運動しているとき】と似たような構造では あるが、健康的だと感じるためには、仲間とスポーツをすることが 必要だと考えられているという違いがある。つまり、運動は 1 人で、 スポーツは仲間で行うという構図が見て取れる。上位概念について
も、【運動しているとき】と同様な構造であるが、運動とは違いスポー ツは楽しむという意識が強いことがわかる。そして、楽しむことで リラックスしていることも読み取れる。

\section{2. カテゴリー「食事」}

カテゴリー「食事」に関して特徵的な構造モデルは【食事をして いるとき】であり、その構造モデルを図 7-3 に示す。下位概念の健 康だと感じる要因として、[家でのんびり過ごす］[仲間がいる][楽 しい］等、時間的余裕や家族や仲間とのコミュニケーションが重要 な要因と言えそうである。また [バランスの良い適量の食事 ] [ 地元 で生産された食物 ] [おいしい食事 ] 等、単にエネルギー源補給の行 為としての食事ではなく、食事の量や内容、生産地といった要因に まで言及しているのがわかる。左側の上位概念を見ると、[食事が おいしいと思える][食材が安心できるもの][リラックスできる [楽しい] 等、精神的な安心感やリラックス感を求めているようで ある。

\section{3. カテゴリー「睡眠」}

カテゴリー「睡眠」に関する特徵的な構造モデルは【よく眠れる とき】【目覚めがよいとき】で、その構造モデルを図 7-4、7-5 に示す。

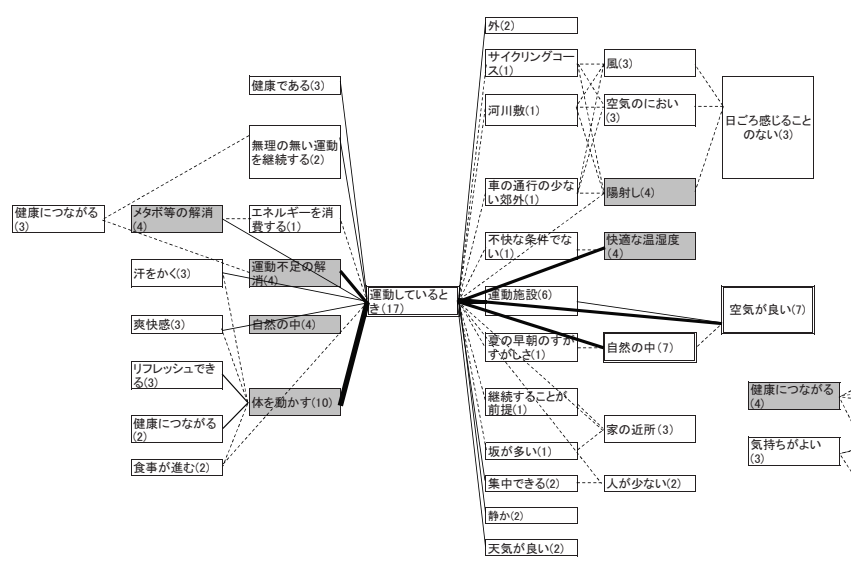

図 7-1「運動」一【運動をしているとき】の構造モデル

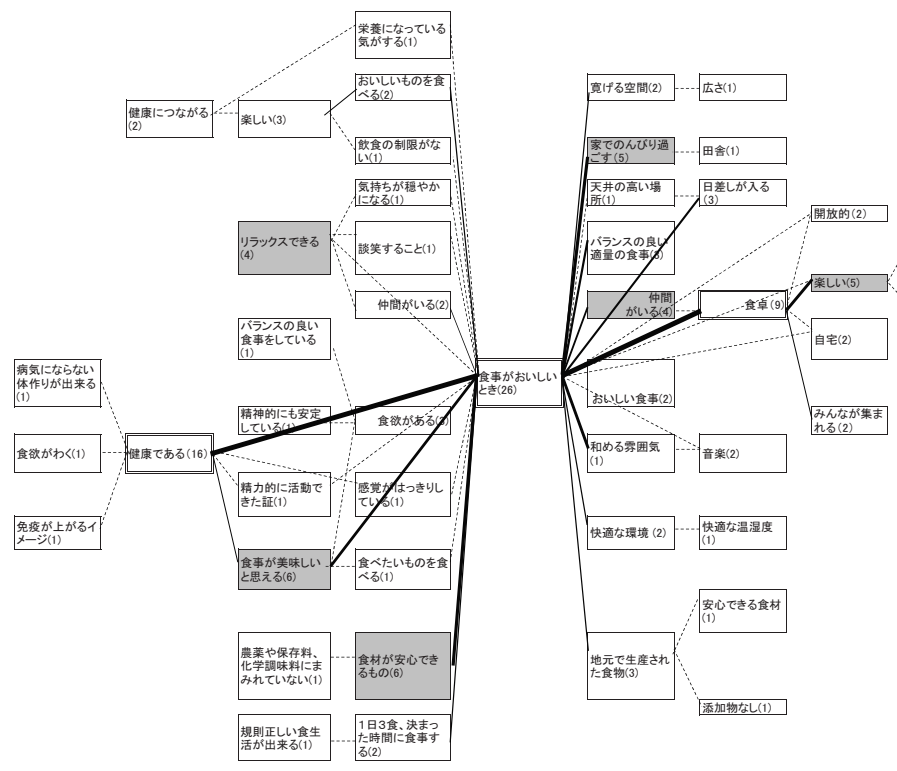

図 7-3「食事」一【食事をしているとき】の構造モデル ※ 図7-1～7-8 は既往研究 1）を基に作成

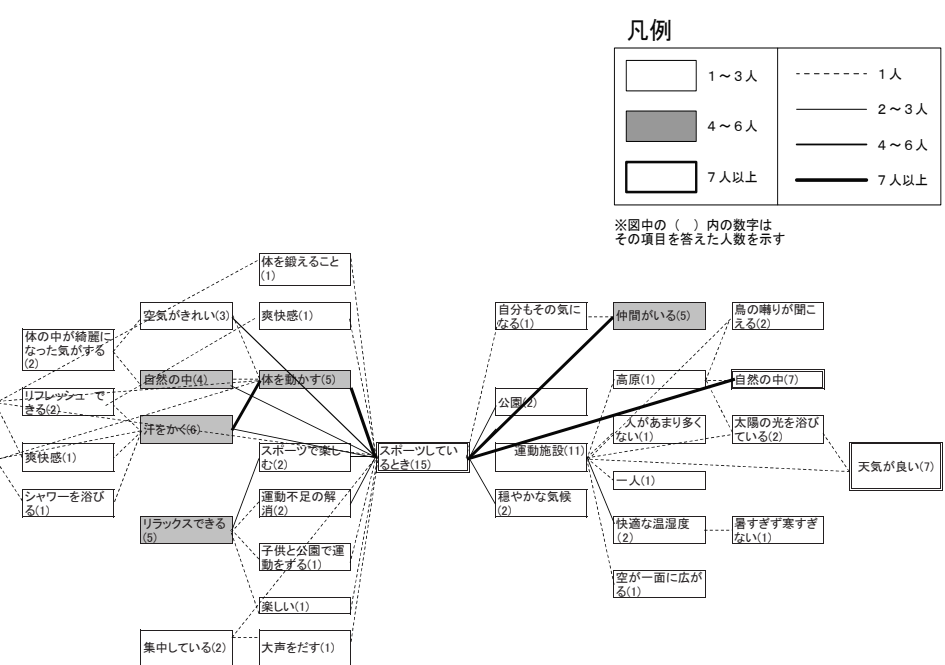

図 7-2「運動」ー【スポーツをしているとき】の構造モデル

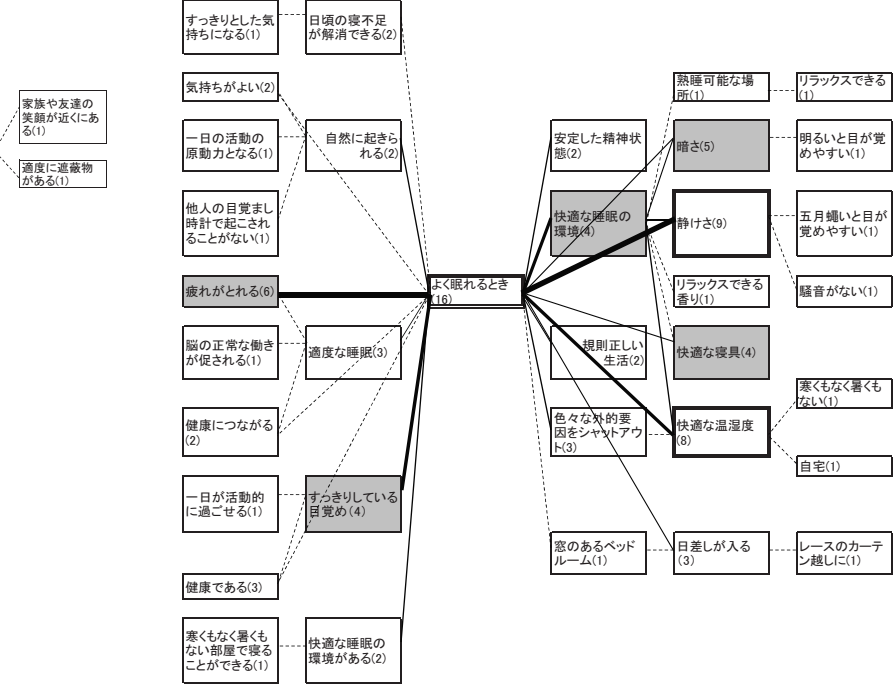

図 7-4「睡眠」ー【よく眠れるとき】の構造モデル 
図 7-4 より、【よく眠れるとき】に関しては、下位概念の健康だ と感じる要因として、［静けさ］[快適な温湿度］[暗さ］[快適な睡 眠の環境 ] [色々な外的要因をシャットアウト ] 等、睡眠のための快 適な温熱環境・光環境といった環境要因が重要のようである。上位 概念の方は [疲れがとれる $][$ すっきりしている目覚め $][$ 適度な睡 眠 ] 等、疲労回復や充実感・満足感が見いだせる

図 7-5の【目覚めがよいとき】では、下位概念に [ 日差しが入る ] [ 快適な寝具 $][$ 静かな環境 $][$ 新鮮な空気が入る $]$ 等、【よく眠れる とき】同様、温熱環境・光環境といった環境要因の重要性が挙げら れる。上位概念の方は、[爽快感 ] [ よく眠れる][ 前向きな 1 日の 始まりとなる ] 等、精神的充実や未来志向的意識の涵養が見いだせ
る。

\section{4. カテゴリー「入浴」}

カテゴリー「入浴」に関する特徵的な構造モデルは【ゆっくり入 浴しているとき】で、その構造モデルを図 7-6に示す。下位概念に [ 入 浴施設］[適度な広さ］等、空間的な要因を挙げており、上位概念では、 [ 新陳代謝が良くなる $][$ リラックスできる $][$ 気分がゆったりする $]$ 等、新たな活力や心休まる感じが見出せる。

\section{5. カテゴリー「思考」}

カテゴリー「思考」に関する特徴的な構造モデルは【自然に笑顔 でいられるとき】で、その構造モデルを図 7-7 に示す。下位概念に [ 仲 間・物に囲まれている $][$ ゆっりくつろいでいる状態 $][$ ほっとす

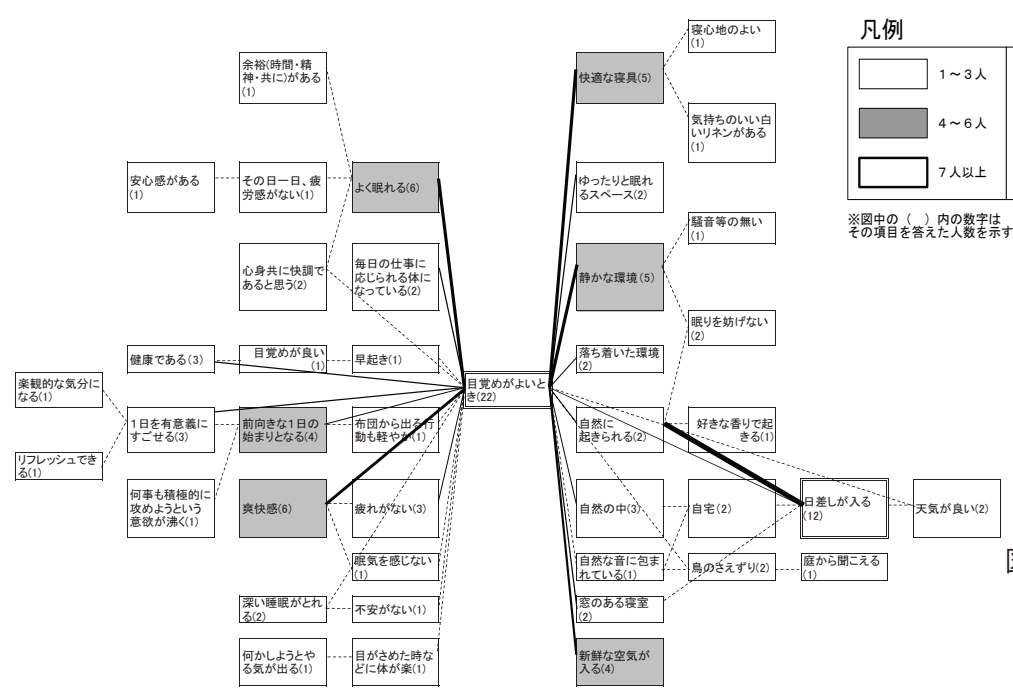

図 7-5「睡眠」一【目覚めがよいとき】の構造モデル

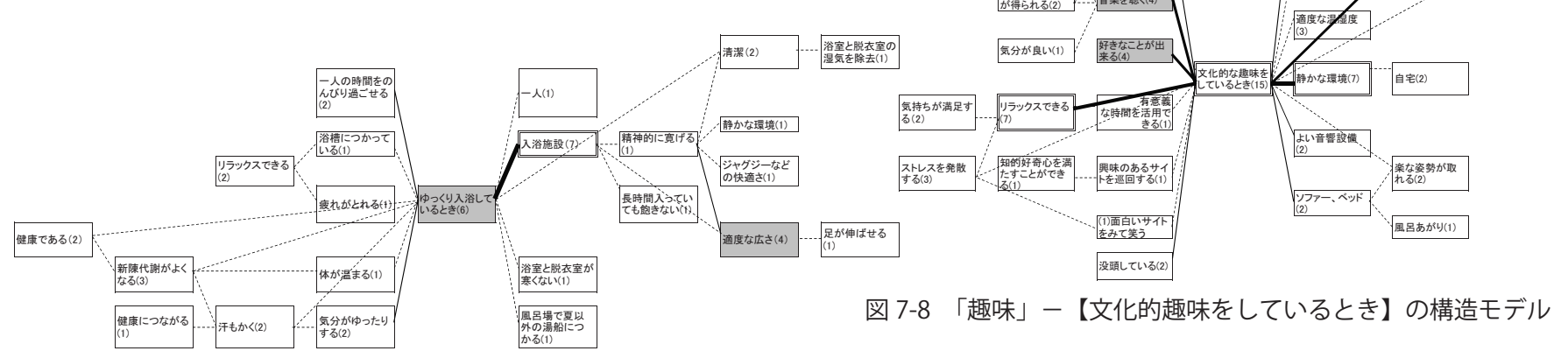

図 7-6「入浴」一【ゆっくり入浴しているとき】の構造モデル

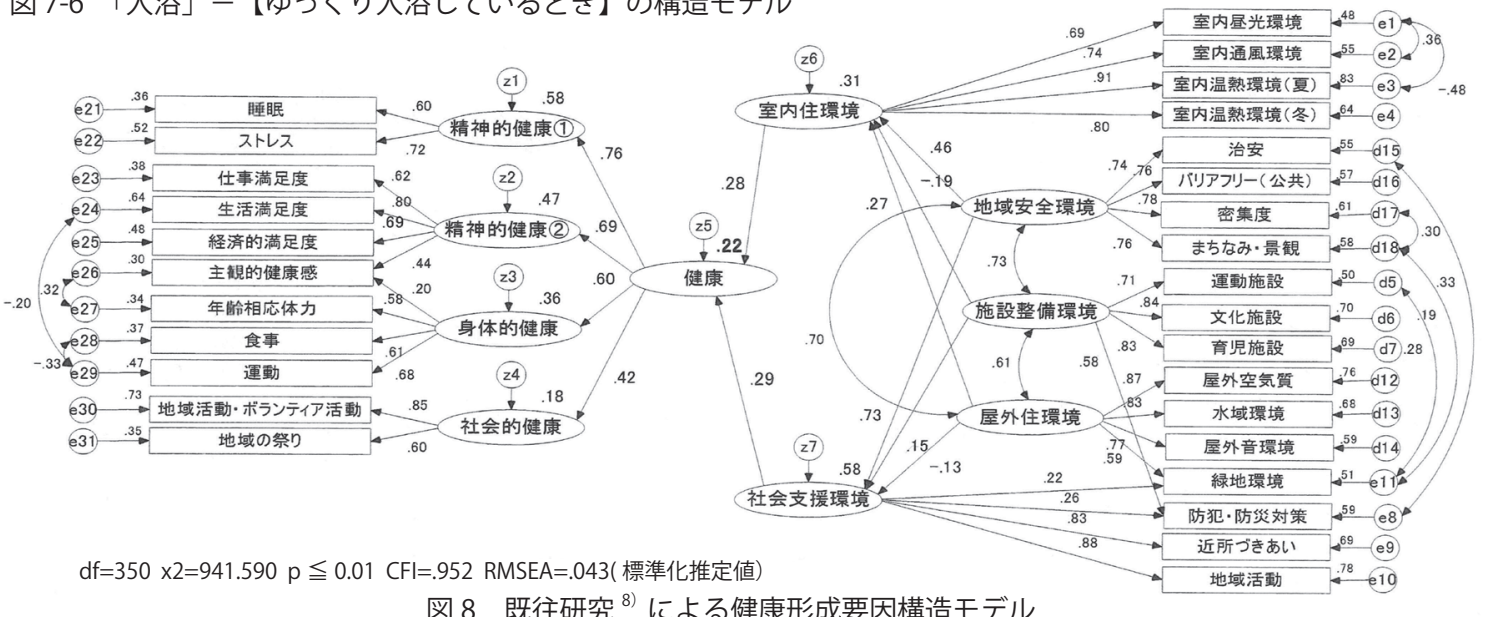

図 8 既往研究 ${ }^{8)}$ による健康形成要因構造モデル 
る住空間 ][リラックスできる]等、精神的にリラックスした状態が 重要であることがわかる。上位概念では、[ 精神的に余裕がある][ 心 の状態が穏やか ] 等、精神的な安定感が見いだせる。

\section{6. カテゴリー「趣味」}

カテゴリー「趣味」に関する特徵的な構造モデルは【文化的な趣 味をしているとき】で、その構造モデルを図 7-8 に示す。下位概念 に [静かな環境 $][$ 一人 $][$ 適度な温湿度 $]$ 等、快適な個人的占有空 間といった意味合いが強い。上位概念では、[リラックスできる ][音 楽を聴く][好きなことができる][ストレスを発散できる］等、精 神的緊張状態を開放できていることがわかる。

\section{6. まとめ}

本研究は、個人的・流動的な概念としての健康に関して、イメー ジグリッド法を用いたアンケート調查により、健康に関する特徴的 形成要因構造モデルを示してきた。

各行動場面ごとに示した構造モデルによって「運動」に関しては、 自然環境との親密性や近親者との人間関係の重要性が明らかになっ た。「食事」に関しては、時間的余裕や家族や仲間とのコミュニケー ションが重要な要因であることがわかった。「睡眠」に関しては、温 熱環境・光環境といった環境要因の整備によって、疲労回復へ繋げ ている様子が見いだせた。「入浴」に関しては、入浴空間の影響が大 きいことが見られ、「思考」に関しては、精神的にリラックスした状 態の重要性が見られた。更に「趣味」に関しては、個人的占有空間 での精神的安定の重要性が見いだせた。

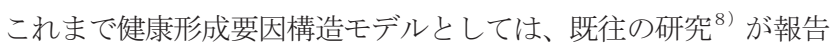
されている。これと本研究の結果を直接比較することは困難である かもしれないが、本研究のような健康に対し帰納的アプローチによ るものと、既往の研究 ${ }^{8)}$ のような演繹的アプローチによるものとを 合わせて見ることで、住環境と健康との関係性を知るという研究全 体を横断的に眺めた場合の新たな知見が見いだせないかと考えた。 そこで、本研究の結果と合わせて見てみると、いくつかの異なる点 が見い出せた。

本研究による健康と特に関係性の高い「運動」、「食事」、「睡眠」 に関して見てみると、「運動」における自然環境との親密性という部 分では、図 8 右下側の潜在变数 : (社会支援環境) と観測变数 :〈緑 地環境〉の部分に当たると考えられるが、そのパス係数は 0.22 と結 びつきは少なく、影響度が低くなっている。これを見ると健康に関 するアンケート調査票においては、自然環境に関する項目をより詳 細に行うことが必要であろう。例えば、一括りに自然環境とするの ではなく、自然との親密性といった項目として、住環境の“自然な 風を感じる”や”空気のにおい等の空気感”、“木漏れ日からあふれ る陽射し”等、単なる環境要因としての “光”や“空気”ではなく、 それをどう感じるかという “感じ方”が重要であり、健康との関連 性が強いようなので、このような項目を追加することで、より詳細 な健康との関連性が見いだせると考えられる。「睡眠」における温熱 環境・光環境といった環境要因の重要性に関しては、図 8 右上側の 潜在变数: (室内住環境) と観測变数: 〈室内昼光環境〉〈室内通風環境〉 〈室内温熱環境 (夏)〉〈室内温熱環境 (冬)〉との影響度はそれぞれ 高いが、潜在変数：(室内住環境) と健康との影響度がパス係数 0.28 と低く、本研究との違いが見られる。また、本研究において特徵的
であった健康と近親者との人間関係の重要性からすると、アンケー 卜項目として“近親者との人間関係”に関するものが必要ではない かと考えられる。このことは、図 8 においては、左下側の潜在変数： (社会的健康)における観測変数 (アンケート調査項目) としての “近 親者との人間関係” という項目を追記することで、より詳細な健康 との関連性が見いだせると考えられる。

住環境と健康との関係性の研究の場合、これまでは、住環境の状 況が健康にどのような影響を与えるかというものが多く見られた が、本研究は健康という概念自体に着目し、健康という概念の構造 モデルを調べることで、住環境と健康との関係性にアプローチした ものである。今後は、これらの知見を健康に関するアンケート調査 票に反映させることで住環境と健康とのより詳細な関係性が明らか になることが期待される。

\section{謝辞}

本研究の一部は、国土交通省に設置された「健康維持増進住宅研究 委員会」ならびに一般財団法人日本サステナブル建築協会に設置さ れた「健康維持増進住宅研究コンソーシアム」の活動の一環として 実施されたものである。調査にご協力いただいた各位、ご助言・ご 指導をいただいた委員会等関係者各位に感謝の意を表します。

\section{参考文献}

1）大井尚行、高橋浩伸、樋渡郁子 : 生活環境における「健康」のイメージ構造 の抽出ーイメージグリッド法の開発一、芸術工学研究 九州大学大学院芸術 工学研究院紀要、pp. 15-27、2011.12

2）吉野博、中村安季、安藤直也、池田耕一、野崎敦夫、角田和彦、北條祥子、 天野健太郎：シックハウスにおける室内環境と居住者の健康に関寸る調查研 究一その 2 宮城県内の 30 軒を中心とした住宅における長期継続観測一、日 本建築学会環境系論文集、第 75 巻、第 654 号、pp. 705-712、2010.08

3）吉野博、長谷川兼一：高断熱高気密住宅における熱環境特性と居住者の健康 に関する調查、日本建築学会計画系論文集、第 507 号、pp. 13-19、1998.05

4）伊香賀俊治、江口里香、村上周三、岩前篤、星旦二、水石仁、川久保俊、奥 村公美 : 健康維持がもたらす間接的便益 (NEB) を考慮した住宅断熱の投資評 価、日本建築学会環境系論文集、第 76 巻、第 666 号、pp. 735-740、2011.08

5）長澤夏子、堤仁美、松岡由紀子、加藤龍一、秋元孝之、田辺新一：居住環境 と家事が慢性疼痛に及ぼす影響の調査と構造分析、日本建築学会環境系論文 集、第 78 巻、第 683 号、pp. 55-61、2013.01

6）長澤夏子、堤仁美、松岡由紀子、加藤龍一、秋元孝之、田辺新一：居住環境 と家事が慢性腰痛に及ぼす影響の属性別分析、日本建築学会環境系論文集、 第 78 巻、第 690 号、pp. 655-660、2013.08

7）川久保俊、伊香賀俊治、村上周三、星旦二、安藤真太郎：環境が居住者の健 康維持増進に与える影響に関する研究一全国の戸建て住宅の環境性能と居住 者の健康状態に関する実態調査一日本建築学会環境系論文集、第 79 巻、第 700 号、pp. 555-561、2014. 06

8）安藤真太郎、白石靖幸、伊香賀俊治、星旦二：共分散構造分析に基づく青壮 年期・高齢期の健康形成要因構造モデルの提案一北九州郊外住宅地における 住宅・地域環境の健康決定要因に関寸る研究, その 1 -日本建築学会環境系 論文集、第 76 巻、第 664 号、pp. 573-580、2011.06

9）安藤真太郎、伊香賀俊治、白石靖幸、星旦二、川村健一、川久保俊、大重和 恵 : 多重指標モデルの構築に基づく青壮年期・高齢期住宅の健康に関する階 層構造分析一住宅と地域環境における健康形成構造の地域間比較一日本建築 学会環境系論文集、第 77 巻、第 675 号、pp. 389-398、2012.05

10）出口満、伊香賀俊治、村上周三、白石靖幸、星旦二、加藤龍一、川久保俊、 安藤真太郎 : 健康維持増進に向けた地域環境評価ツールの開発と有効性の検 証、日本建築学会環境系論文集、第 77 巻、第 681 号、pp. 837-846、2012. 11

11) 総務省統計局、平成 23 年社会生活基本調查報告第 1 巻全国生活時間編（調 査票A )、p.7、2013.03 


\title{
STUDY ON THE HEALTH RELATED FACTOR MODEL BY THE IMAGE GRID METHOD
}

\author{
Hironobu TAKAHASHI ${ }^{*}$ and Naoyuki OI** \\ * Assoc. Prof., Faculty of Environmental \& Symbiotic Sciences, \\ Prefectural University of Kumamoto, Dr.Eng. \\ ** Assoc. Prof., Faculty of Design, Kyushu University, Dr.Eng.
}

The concept of "health" is thought to be important to today's housing. In order to overcome the difficulty in investigating the concept of "health", the Image Grid Method was developed from Evaluation Grid Method and the concept of Behavior settings in our previous study.

A questionnaire survey on "health" was conducted using the Image Grid Method in 2009 on 75 people of various attributes: living area, gender, age, housing type, health condition etc.

From the responses, behavior settings mentioned were categorized and resulted in 10 categories and subcategories called "unit". 10 categories are physical exercise, meal, sleep, bathing, family, nature, thinking, hobby, work and the other miscellaneous. Physical exercise, meal and sleep are the three major categories related to "health", whose cumulative rate is over $60 \%$.

As the Image Grid Method includes the process of laddering up and down, responses are not only the individual items but the relation between items are obtained as the original data, which is the advantage of the method. The health related factor model is discovered from the evaluation structural models of each category built from the original data of the Image Grid Method.

The model about physical exercise shows the importance of the intimacy with the nature and the relationship with the close relatives. The model about meal shows that spare time and the communication with the family or associates are the important factors. The model about sleep shows that the improvement of thermal and visual environment leads to the restoration from fatigues. The other models show that bathing environments, mental relaxation and mental stability in the personally occupying space are also important.

These results are found to be the complementary knowledge with the previous studies on the health related factors using other approaches. 